\title{
Editorials
}

\section{COVID-19 and the legacy of grief}

As the first wave of this pandemic, effectively unprecedented in all of our lifetimes, begins to subside, ${ }^{1}$ we find ourselves confronting a legacy of grief and loss, which seems likely to be continually replenished as the disease rolls on. An understanding of the breadth and depth of this legacy will be essential to effective and humane health care over decades to come.

\section{THE MIDDLE OF THE STORY}

The most immediate and obvious form of grief is felt by those who have lost parents, life partners, children, and dear friends, both young and old, and we must acknowledge that some communities, particularly those subject to the structural violence of poverty and racism, have been significantly more exposed to this than others. Much of this anguish has been compounded by being obliged to let these precious people die alone with a minimal funeral, and no real opportunity to say goodbye and draw a loving relationship to a proper close. ${ }^{2}$ And too many survivors of the most serious variants of the disease are facing futures marred by chronic ill health with widespread damage to organ systems apparently caused by a destructive immunological response to the SARS-CoV-2 virus. ${ }^{3}$

All this is made much worse by the feeling that many of the deaths and at least some of the life-changing damage could have been avoided if our society and the NHS had been better prepared and not so seriously undermined by the foolish and ideological imposition of austerity. There can be no getting away from the fact that we have had, to date, by far the worst death rate in Europe. And this becomes a wider source of grief as we are all obliged to acknowledge that we can no longer cling on to our previous sense of living in a wellrun country with high standards of justice, inclusion, and competence.

The grief of those who are seeing their anticipated futures crumble - in terms of education, employment, and small business, or indeed, the breakdown of relationships, catastrophic loneliness, the rise of intimate partner violence, and the erosion of mental health - will prove to be no less important to future health care. And, it may be worryingly easy to minimise the grief of children: all those Year 6 children who have completely lost what they anticipated would be the best term of their primary school careers, with the school journey, the play, and the adulation of the years below them. They will never get this chance again and the effect on their future in secondary school is not yet clear. Such irretrievable losses are being replicated across every stage of education through childhood, adolescence, and young adulthood, and the losses of the young will also grieve their parents and carers. Parents who have not been able to help their children to keep up with home learning and who see their children falling behind will feel grief made worse by guilt and anger.

\section{LOOKING FORWARD}

These are just some of the multifarious griefs that will touch almost everybody to at least some extent. This means that a new question will need to be added to the repertoire of every GP, something along the lines of "How has the pandemic affected you?' The question is the beginning of an attempt to understand and to pay attention to the pervasiveness of grief, the stresses of which have the power to undermine future health. The processing and surviving of such profound sadness have been dependent on culture, ritual, and relationships since the beginning of human time and will continue to do so.

GP care occurs in two major arenas: the transactional and the relational, and both are essential. However, the technical and transactional skills of GPs have almost no role to play in the support of those struggling with grief while a strong oneto-one relationship of mutual respect and trust can be immensely powerful. Relationship-building is an investment that has the potential to make future care easier for both patient and GP, and the posing of the 'pandemic question' can be a way not only of beginning but also of strengthening a therapeutic relationship. In this context, it will be very important to resist the temptation to pathologise, label, or precipitately refer on the sequelae of grief, because all of these undermine the potential of using shared understanding to cement such a relationship. We must hope that one of the few positive legacies of the pandemic can be a rediscovery of the power of therapeutic relationships within a context of personal continuity of care, ${ }^{4}$ much of which has been so destructively

\section{ADDRESS FOR CORRESPONDENCE}

Iona Heath

Email: iona.heath22dyahoo.co.uk

undermined by healthcare policy over recent decades.

In a recent essay, Canadian poet and writer, Anne Michaels wrote:

Grief, loss, regret are not the end of the story. They are the middle of the story. Memory does not look backward, it looks forward."

The distress we see all around us is the middle of the pandemic story. There is a huge amount to see, to hear, to understand, and to do in order for us all to reach the end of the story and to find meaning in it.

\section{Iona Heath,}

Retired GP; Former President of the Royal College of General Practitioners, London.

\section{Provenance}

Commissioned; not externally peer reviewed.

\section{Competing interests}

The author has declared no competing interests.

DOI: https://doi.org/10.3399/bjgp20X712181

\section{REFERENCES}

1. The Centre for Evidence-Based Medicine. Oxford COVID-19 evidence service. 2020. https://www.cebm.net/oxford-covid-19evidence-service laccessed 29 Jul 2020).

2. Boland MJ. A hard time to die: grief and the coronavirus. Br J Gen Pract 2020; DO https://doi.org/10.3399/bjgp20X710513.

3. National Institute for Health Research. Major study into long-term health effects of COVID19 launched in the UK. 2020. https://www. nihr.ac.uk/news/major-study-into-long-termhealth-effects-of-covid-19-launched-in-theuk/25200 (accessed 29 Jul 2020)

4. Pereira Gray DJ, Sidaway-Lee K, White E, et al. Continuity of care with doctors - a matter of life and death? A systematic review of continuity of care and mortality. BMJ Open 2018; 8(6): e021161.

5. Michaels A. Mortal soul, moral soul. What happens when private grief becomes common experience? Lapham's Quarterly 2020; XIII(1): Winter 2020. https://www. laphamsquarterly.org/memory/mortal-soulmoral-soul (accessed 29 Jul 2020). 